\title{
The Foraminiferal assemblages across three middle Turonian marl bands and a note on their genesis
}

\author{
P.N. LEARY' \& D. S. WRAY ${ }^{2}$ \\ 'Department of Geological Sciences, Polytechnic South West, Drake Circus. \\ Plymouth, Devon PL4 8AA. \\ ${ }^{2}$ School of Earth Sciences, Thames Polytechnic, Walburgh House, Bigland Street, \\ London, EI 2NG
}

\begin{abstract}
Foraminiferal assemblage across three Middle Turonian marl bands show a consistent pattern, with (a) very similar gross assemblage characteristics from the white chalk below and above the marls containing an approximately $60: 40 \%$ planktonic:benthonic ratio, greater than $50 \%$ non-keeled morphotypes (within the planktonic assemblage) and with infaunal and epifaunal groups well represented but (b) from within the marls the assemblage is dominated by benthonics $(30: 70 \%$ p:b ratio), less than $20 \%$ non-keeled morphotypes (within the planktonic assemblage) and a benthonic assemblage dominated by the infaunal groups. Although there is evidence of some dissolution within the marls, with the pitting of the thinner test walls, we propose the changes in the assemblage are not due to large scale post mortem diagenetic process. But are most likely due to environmental changes within the chalk sea, possibly caused by the ephemeral introduction into the surface waters of volcanic ash.
\end{abstract}

\section{INTRODUCTION}

Marl bands are clay rich units which are found in parts of the Middle and Upper Turonian chalk of southern England. Brydone (1914) recognised their potential for lithostratigraphic correlation because of their seemingly consistent representation over considerable areas. More recently these marls have formed the basis for the detailed correlations in the chalk of the North Downs (Robinson, 1986), the South Downs (Mortimore, 1986) and across the whole Anglo-Paris Basin (Mortimore \& Pomerol, 1987). Despite their apparent great lithostratigraphic value, relatively little is known about the origin of these marl bands. This study concerns the analysis of the foraminiferid assemblages recovered from below, within and above three Middle Turonian marls (New Pit Marl 1, New Pit Marl 2 and the Glynde Marl 1.)

\section{LOCATION OF SAMPLES}

The marl bands discussed here were all collected from a road cutting approximately $2 \mathrm{Km}$ south of Burghclere, Berkshire (SU 475589) (Fig. 1). It is unfortunately no longer exposed, but lateral equivalents are readily available at other localities in the south of England (see Mortimore, 1986; Robinson, 1986; Mortimore \& Pomerol, 1987).

\section{I.ITHOSTRATIGRAPHY AND BIOSTRATIGRAPHY}

The sequence of rocks investigated are within the Ranscombe Member, of the White Chalk Formation (Gale et al., 1987) and is contained within the top of the Terebratulina lata Zone (Fig. 2) although this macrofaunal marker was not found in the microfaunal preparations. The presence of Helvetoglobotruncana helvetica (Bolli) and Marginotrun rana sigali (Reichel) within the foraminiferal assemblage

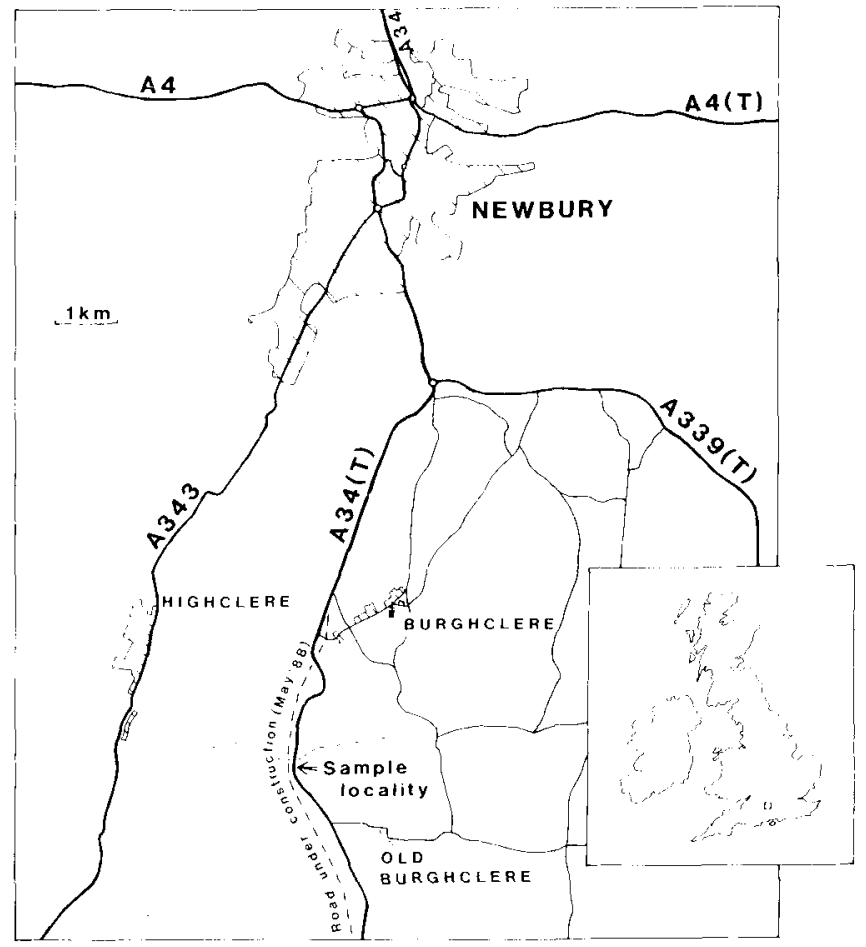

Fig. 1 Locality map

places the sequence within the $H$. helvetica total range zone of Robaszynski \& Caron (1979); although the stratigraphic reliability of the distribution of some Turonian planktonic marker species in English sections has been questioned (Hart, 1982). 


\section{SEDIMENTOLOGY}

A marl seam is defined here as a thin $(2-20 \mathrm{cms})$, laterally extensive bed of chalk which contains a large percentage (15-35\%) of non-carbonate material. Up to $80 \%$ of the noncarbonate fraction is composed of clay minerals (smectite and illite), the remaining $20 \%$ is dominantly composed of quartz, iron oxides and apatite (Robinson, 1984). In contrast, the white chalk above and below the marl seam only contains between 0.5 and $3 \%$ non-carbonate material. The contact of a marl seam with white chalk can be either sharp or gradational. If the contact is sharp and well-defined, irregular fingers ("flasers") of marly (non-carbonate rich) chalk are usually seen extending a few centimetres into the white chalk, these are believed to be a product of bioturbation (Wray, in prep.). The term marl band is used to define the complete unit, including both the marl seam and any other associated beds which contain marly chalk.

New Pit Marl 1 contains an $8 \mathrm{~cm}$. thick seam of firm, medium, grey, marly chalk, which has white chalk above and below it. The lower contact with the white chalk is flasered, with individual flasers continuing downwards for up to $9 \mathrm{~cm}$.
In contrast, the upper contact appears gradational. Within the marl seam there is evidence of bioturbation with burrows including Chondrities and Thalassinoides. Occasional white intraclasts can also be seen within the seam (Fig. 2).

New Pit Marl 2 at this locality differs from N.P. 1 in that the seam is thicker $(20 \mathrm{~cm}$.), and has a slightly plastic texture. Light to medium grey flasers pass downwards from the marl seam into white chalk to a depth of $6 \mathrm{~cm}$., the upper contact of the seam again appears gradational. The marl seam shows poor evidence of bioturbation (possibly Thalassinoides). It is possible to recognise a tripartite subdivision of this seam where the middle portion is more plastic than the parts above and below and contains isolated white burrows (Fig. 2.)

Glynde Marl 1 is thinner than the other two. It contains a $3 \mathrm{~cm}$. seam of dark-brown, plastic, marly chalk. Both contacts with the white chalk above and below appear gradational, although below the seam isolated flasers can be seen extending to a depth of $5 \mathrm{~cm}$. Above the seam proper. where the chalk is still a light grey in colour, it is possible to see occasional lighter burrows (Fig. 2).

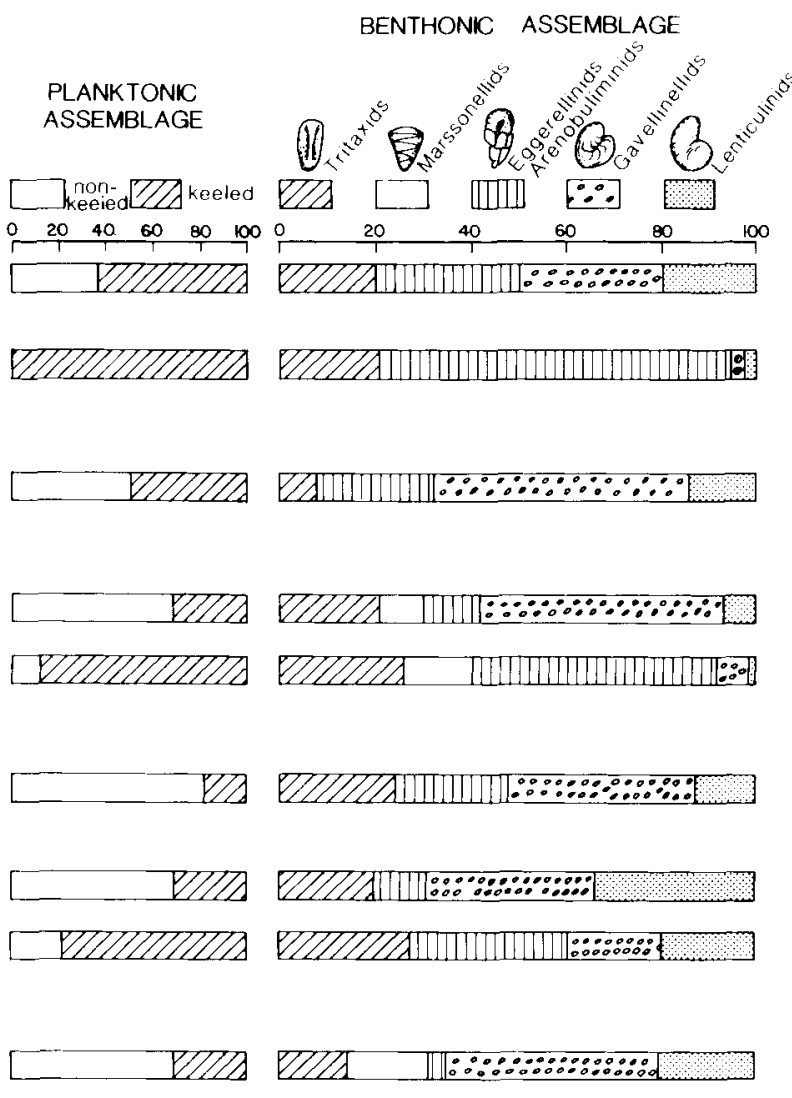

Legend

PLANKTONK

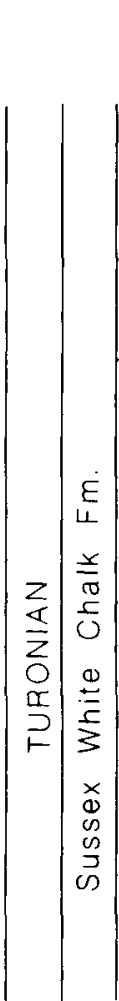

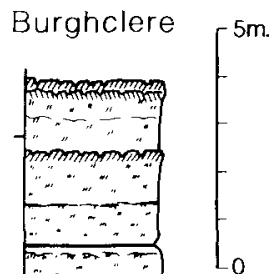

\section{m.}

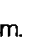

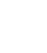

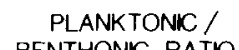
BENTHONIC RATIO EZZAPiank. $\square$ Benth.

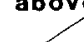
above

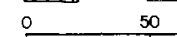
0 100 100 Gre EDPDPTP
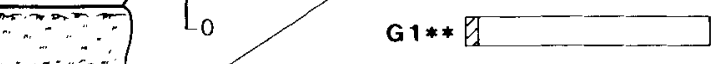

-

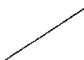

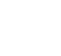

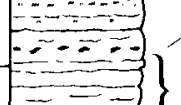

GLYNDE

below G1 पEZIIT

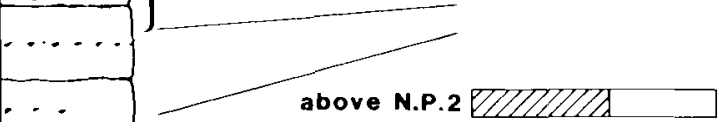
MEW PIT

N.P. $2 * * * \square$

$\cdots \cdots-1$
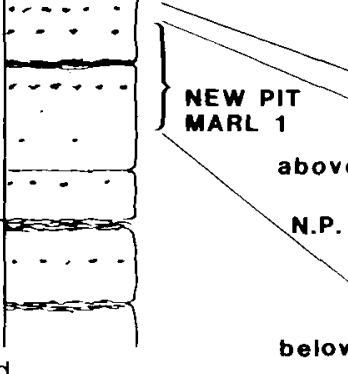

below

P. 2 घLIIIIIII

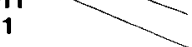

above N.P.1* VIIZIIIIIA

N.P. 1

*** VIIA

below N.P.1 * QIIIIIIIA

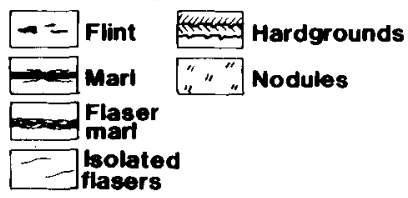

Fig. 2 Foraminaferal assemblages across the three marl bands 
The foraminiferal assemblages aross three middle Turonian marl bands

\section{GENESIS OF THE MARLS}

Previous modelling of Cretaceous marl development falls into two camps; primary (detrital) or secondary (due to dissolution of calcium carbonate).

\section{Primary Models:}

The possibility that marl seams represented airborne ashfalls was first suggested by Brydone (1914) as an explanation for their great lateral extent. More recently, Valeton $(1959,1960)$, Dorn and Brautigam (1959) and Seibertz and Vortisch (1979) described volcanic tuff horizons within the chalk of Germany, noting that they contained volcanic glass, clays (illite, kaolinite, illite/smectite and Fe-beidellite), feldspar, mica and heavy minerals. These horizons occur in both the Middle and Upper Turonian of northwestern Germany and some have been used in regional correlation (Ernst, Schmid and Seibertz, 1983). Pacey (1984) proposed a similar (volcanic) origin for marl bands from the Chalk of Lincolnshire and Yorkshire, basing his argument on a combination of petrological and geochemical results. He suggested that the ashfalls were produced during the opening of the northeast Atlantic, possibly from the Anton Dohrn Seamount in the Rockall Trough. Although the Chalk of southern England does not contain marl seams with the "exotic" minerals found in Germany (possibly due to distance from source or post-depositional alteration), geochemical evidence (Wray, in prep.) shows that it is possible to recognise individual Turonian marl seams on their clay mineral trace element geochemistry. Each marl has a unique "fingerprint" which remains constant over large distances (Kent-Sussex-France). Whilst not clearly proving a volcanic origin for the marls, it is difficult to envisage an alternative process which could produce a similar result.

In contrast to the above, Jefferies (1963) suggested that current activity may be responsible for the formation of marl seams. Although dealing specifically with the Plenus Marl Formation (Cenomanian), he felt that his model of increased clastic input caused by river rejuvenation related to sea-level fall might be applicable to other marl seams as well. Alternative models for the genesis of the Plenus Marls are available elsewhere (Jarvis et al., 1988; Leary et al., 1989). Robinson (1984) also suggested that current activity might be important in increasing the extent of marl seams, although he believed that they were originally of volcanic origin.

\section{Secondary Models:}

Ernst (1978, 1982) has proposed that marl bands may be formed through selective dissolution of calcium carbonate during sedimentation. He carried out a quantitative analysis of foraminifera across a Maastrichtian marl band within the north Grerman Chalk (marl layer M100), for which a volcanic origin had been previously proposed (Valeton, 1960). He found that the parametres studied (including planktonic:benthonic ratio, degree of corrosion and percentage of certain species) showed a systematic shift across the marl band which commenced some distance below it. He argued that his results showed a slow, but continuous, increase in the quality of nutrients being introduced into the system, reaching a peak within the marl seam. The decomposition of the organic matter increased the amount of $\mathrm{CO}_{2}$ at the sediment water interface, causing a lowering of the $\mathrm{pH}$ and an increase in $\mathrm{CaCO}_{3}$ dissolution. A similar model has been proposed by Curry (1982) for marl seams within the English Chalk.

\section{FORAMINIFERAL CHANGES ACROSS THE MARLS AND INTERPRETATION}

In general the Turonian benthonic assemblage is one of low diversity as a result of the slow recolonisation by the benthos after the extinctions during the late Cenomanian oceanic anoxic event (Owen, 1970; Woodroof, 1981; Horn et al., in press; Leary, in prep.) whereas the planktonic assemblage shows a more rapid proliferation during this interval (Leary, 1987).

A subjective index of the degree of dissolution of the foraminiferid tests is included (* a little surface pitting, ${ }^{* *}$ small holes, *** extensive damage) as the preservation of Upper Cretaceous foraminifera can be poor (Curry, 1982). It is worth noting that the effects of dissolution are not confined to marl seams.

The foraminiferid assemblages across the three marls are shows in Fig. 2 and the results are summarised below -

(a) the pre-marl and post-marl foraminiferid assemblages are dominated by the planktonic groups with planktonic specimens forming at least $55 \%$ of the total assemblages. In all but one sample (above N.P. 1) the planktonic assemblage is dominated by non-keeled morphotypes, but even here they form $40 \%$ of the planktonic assemblage. Within the benthonic assemblages the pre-marl assemblage is dominated by the gavelinellids with the lenticulinids, eggerellinids/arenobuliminids and the tritaxids being reasonably represented. The post-marl assemblages show in two cases (N.P. 1 \& G.1) assemblages with increases from the pre-marl percentages in the presence of the lenticulinids, eggerellinids/arenobuliminids and tritaxids and a decrease in the relative percentage of the gavelinellids. In contrast the post-marl benthonic assemblage of N.P. 2 shows a slight increase in the relative percentage of the gavelinellids and reductions in the tritaxids and lenticulinids. The pre N.P. 1 marl and the post N.P. 1 and G. 1 samples exhibited low dissolution (Fig. 2).

(b) intra-marl assemblages are dominated by benthonics with $p: b$ ratios up the sequence of 30:70, 15:85 and 5:95 respectively. The planktonic assemblage is dominated by the keeled forms in all cases. The benthonic assemblage is dominated each time by eggerellinids/arenobuliminds and trataxids but the gavelinellids and lenticulinids are still represented. In all three marl samples there was evidence of dissolution but the calcareous forms were still readily recognisable and there was no apparent size fractionation.

The modelling performed on the function morphology of Cretaceous planktonic foraminifera suggests that keeled morphotypes underwent gametogenesis deeper in the water column than the non-keeled groups (Wonders, 1980; Hart, 1980; Caron, 1983) and within the tests of the near surface 
living extant forms light dependent symbionts are present. The modelling performed on the benthonic Cretaceous foraminifera suggests that the gavelinellids and lenticulinids were epifaunal dwelling and that the tritaxids, marssonellids and eggerellinids/arenobuliminids were infaunal dwelling groups (Corliss, 1985; Jones, 1986; Jones \& Charnock, 1985).

Thus the changes across the marl seams may be summarised as -

(i) the planktonic assemblage, particularly the surface dwelling forms, are severely affected.

(ii) the epifaunal dwelling groups are severely affected. These changes are consistent with the rapid introduction into the water column of volcanic ash which built up on the sea floor forming the marl seam (Fig. 3). The turbid ash laden surface waters severely affected the planktonic foraminifera (particularly the symbiont bearing near surface dwellers). In addition the clay drape severely disrupted the epifaunal groups (gavelinellids and lenticulinids) but had little affect on the infaunal groups. Ernst's (1978), 1982) observation that changes in the foraminifera commence before deposition of the marl seam, only peaking within the marl (see Ernst, 1982, figs. $3 \& 8$ ), is likely to be a result of bioturbation. His diagrams suggest that flasers of marly chalk pass upwards and downwards from the M100 marl seam. Samples from these regions will therefore contain a mixture of white and marly chalk (from the marl seam), giving rise to more gradual variations.

\section{CONCLUSIONS}

The changes in the foraminiferid assemblage across three Turonian marl seams of southern England are consistent with the affects of the introduction of volcanic ash into the surface waters. Although the marl seams of southern England lack some of the more exotic minerals found in the German marls, this may simply be related to factors such as distance from source and/or post-depositional alteration. The most likely origin for the volcanic material is the midAtlantic Ridge; this will be discussed elsewhere (Wray, in prep.). We believe that other models for marl formation have placed undue emphasis on the partial dissolution of some of the foraminiferal tests. High turbidity in the surface waters would also curtail temporarily nannoplankton production and this would also help explain the low carbonate values recorded from the marls.

\section{ACKNOWLEDGEMENTS}

This work was undertaken whilst Dave Wray was in receipt of an I.L.E.A. Research Assistantship and Paul Leary was in receipt of a L.E.A. Postdoctoral Research Fellowship. The comments of Andrew Gale and Malcolm Hart were most useful in the preparation of the Manuscript. The most helpful and diligent technical assistance of Ian Slipper is gratefully acknowledged

\section{Manuscript Received 1989 \\ Revised Manuscript accepted May 1989}

\section{REFERENCES}

Brydone, R.M. 1914. The Zone of Offaster Pilula in the south English Chalk. Geol. Mag. 51, 449-457, 509-513

Caron, M. 1983. La speciation chez les Foraminiferes plantiques: une response adaptee aux constraintes de l'environment. Zitt., 10, 671-676

Corliss, B.H. 1985. Micro-habitats of benthonic foraminifera within deep see sediments. Nature, 314, 435-438.

Curry, D. 1982. Differential preservation of foraminiferids in the English Upper Cretaceous-consequential observations. In, Banner, F.T. \& Lord, A.R. (Eds.). Aspects of Micropalaeontology, George Allen \& Unwin.

Dorn, P. \& Brautigam, F. 1959. Hinweise auf Oberkreide vulkanismus in Norwestdeutschland. Abh. Braunschw. Wiss. Ges., 11, 1-4

Ernst, H. 1978. Zu Bathymetrie und Sedimentrunkturen der Schreibkreide von Lagerdorf/Holstein (Coniac.-Santon.): Eine quantitative Analy se der Foraminifere-Faunen. Mitt. geol-palaontol. Ist. Univ. Hambarg. 45, 53-78

Ernst, H. 1982. The marl layer M 100 in the Maestrichtian of Hemmoor - an example of selective $\mathrm{CaCO}_{3}$ dissolution. Geol. Jb., A61, 109-127

Ernst, G., Schmidt, F. \& Seibertz, E 1983. Event-Stratigraphie im Cenom und Turon von NW-Deutschland. Zitteliana 10,531-5.54

Gale, A.S., Wood, C.J. \& Bromley, R.G. 1987. The lithostratigraphy and marker bed correlation of the White Chalk (late Cenomanian -Campanian) in southern England. Mesozoic Research, 1. (2), 107-118

Hart, M.B. 1980 A water depth model for the evolution of the planktonic Foraminiferida. Nature, 286, 5770, 252-254.

Hart, M.B. 1982. Turonian foraminiferal biostratigraphy of southern England. Mem. Mus. Nat. D'Hist. Nat., 46, 203207.

Horne, D., Jarvis, I \& Rosenfeld, A. in press. Recovering from the effective of an occanic anoxic event; Turonian Ostracoda from S.E. England. In, Ostracoda and Global Ev'ents, Whately, R. Ed., Ioth. Inst. Sym Ostra., Univ. Aberyst.

Jarvis, I., Carson, G.A., Cooper M.K.E., Hart, M.B., Horne D. Leary, P.N. Rosenfeld, A. \& Tocher, B.A. 1988. Microfossil assemblages and the Cenomanian-Turonian (late Cretaceous) anoxic event. Cret. Res., 9. 3-103.

Jefferies, R.P.S. 1963. The stratigraphy of the Actinocamax plents Subzone (Turonian) in the Anglo Paris Basin. Proc. Geol. Assoc., 74, 1-33.

Jones, R.W. 1986, Distribution of morphogroups of Recent agglutinating foraminifera in the Rockall Trough - a synopsis. Roy. Soc. Edin., Procs., 88b, 55-58.

Jones, R. W. \& Charnock, M.A. 1985. "Morphogroups" of agglutinating foraminifera. Their life positions and feeding habits and potential applicability in (paleo)ecological studies. Revue de Paleobioge, 4, 2. 311-320

Leary, P.N. 1987. The late Cenomanian anoric e'ent; implications for foraminiferal evolution. Unpub. PhD thesis. CNAA. Plymouth Polytechnic. 
The foraminiferal assemblages aross three middle Turonian marl bands
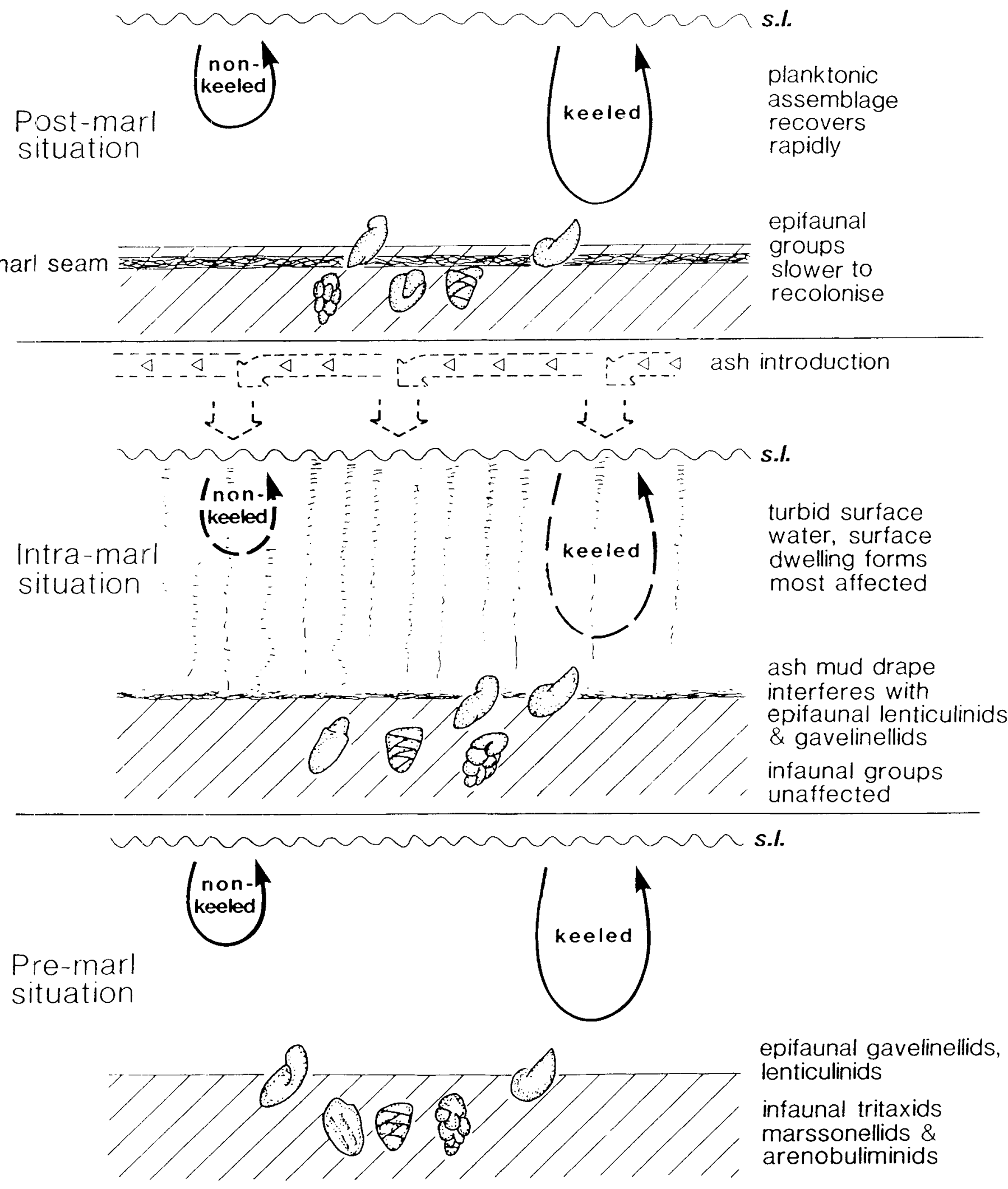

Fig. 3 Idealised foraminaferal response to volcanic ash 
Leary, P.N., Carson, G.A., Cooper, M.K.E., Hart, M.B., Horne, D., Jarvis, I., Rosenfeld, A. \& Tocher, B.A. 1989. The biotic response to the late Cenomanian oceanic anoxic event, integrated evidence from Dover, S.E. England. J. Geol. Soc. Lond., 146, 311-317.

Mortimore, R.N. 1986. Stratigraphy of the Upper Cretaceous White Chalk of Sussex. Proc. Geol. Assoc., 97, 97140.

Mortimore, R.N. \& Pomerol, B. 1987. Correlation of the Upper Cretaceous White Chalk (Turonian to Campanian) in the Anglo-Paris Basin. Proc. Geol. Assoc., 98, 97-143.

Owen, M. 1970. Turonian foraminifera of southern England. Unpub. PhD thesis, Univ, of Lond.

Pacey, N.R. 1984. Bentonites in the chalk of central eastern England and their relation to the opening of the northeast Atlantic. Earth. Plan. Sci. Lett., 67, 48-60

Robaszynski, F. \& Caron, M. 1979 Atlas de foraminiferes planctoniques du Cretace moyen (mer Boreale et Tethys). Cahiers de Micropaleontologie, Edits, Cent. Nat. Recherche Sci., Parts 1 \& 2.

Robinson, N.D. 1984. Lithostratigraphy and sedimentology of the Chalk in the North Downs, southeast England. Unpub. PhD thesis, CNAA, Kingston Polytechnic.
Robinson, N.D. 1986. Lithostratigraphy of the Chalk group of the North Downs, southeast England. Proc. geol. Assoc., 97, 141-170.

Seibertz E. \& Vortisch, W. 1979. Zur stratigraphie, petrologie und genese einer Bentonit-lage aus dem oberen MittleTuron (oberkreide) de sudostlichen Munsterlandes. Geologishe Rundschau, 68, 649-679.

Valeton, I. 1959, Eine culkanishe tufflager aus de Oberkreide von Hemmoor/Niederelbe. Neus. Jahrb. geol. Palaontol. Montash., 5, 195-204.

Valeton, I. 1960, VulKanishe Tuffiteinlaerung in der nordwesdeutschen Oberkreide. Mitt. Geol. Staatsinst., Hamburg, 29, 26-41.

Wonders, A.A.H. 1980. Middle and Late Cretaceous planktonic foraminifera in the western Mediterranean area. Utr. Micropal. Bull. 24, 5-156.

Woodroof, P.B., 1981. Faunal and stratigraphic studies in the Turonian of the Anglo-Paris Basin., Unpub. $\mathrm{PhD}$ thesis, Univ. of Oxford. 